\title{
GOMMENT
}

\section{FROM DURESS TO INTENT: SHIFTING THE BURDEN IN PRISON-ESGAPE PROSECUTIONS}

In the early morning hours of August 26, 1976, Glifford Bailey, Ronald Clifton Cooley, and Ralph Walker escaped from the New Detention Center of the District of Columbia Jail. ${ }^{1}$ They were not apprehended until September 27, November 19, and December 13, 1976, respectively. ${ }^{2}$ On November 23, 1976 the three men were indicted under the federal escape statute. ${ }^{3}$ At their trial, the defendants did not deny that they had escaped from jail. ${ }^{4}$ Instead, they presented evidence to the jury to establish that there had been

frequent fires . . . set by both inmates and guards, and often allowed to burn while the inmates suffered from lack of proper ventilation, that [they] had been threatened with physical violence by guards, that . . . Bailey and Cooley had actually been beaten by guards, that . . . Walker had epilepsy and had received inadequate medical treatment for his condition, and that . . . Cooley had been forced by his co-[defendants] to leave the jail. ${ }^{5}$

The trial judge instructed the jury that such prison conditions, " "no matter how burdensome or restrictive an individual inmate may find

1 United States v. Bailey, 585 F.2d 1087, 1090 (D.C. Cir. 1978), cert. granted, 47 U.S.L.W. 3621 (U.S. 1979) (No. 78-990).

2 Id. 1106 (Wilkey, J., dissenting).

3 Whoever escapes or attempts to escape from the custody of the Attorney General or his authorized representative, or from any institution or facility in which he is confined by direction of the Attorney General, or from any custody under or by virtue of any process issued under the laws of the United States by any court, judge, or magistrate, or from the custody of an officer or employee of the United States pursuant to lawful arrest, shall, if the custody or confinement is by virtue of an arrest on a charge of felony, or conviction of any offense, be fined not more than $\$ 5,000$ or imprisoned not more than five years, or both; or if the custody or confinement is for extradition or by virtue of an arrest or charge of or for a misdemeanor, and prior to conviction, be fined not more than $\$ 1,000$ or imprisoned not more than one year, or both.

18 U.S.C. $\$ 751$ (a) (1976).

4585 F.2d at 1106 (Wilkey, J., dissenting).

5 Id. 1091 (citations omitted). Judge Willey, writing in dissent, challenged each of these allegations, asserting that "there was no evidence of $a$ fire on 26 August 1976, the day of the escape"; that, although a group of guards attacked Bailey, "[t]his incident occurred, according to the inmate [who testified at trial], more than three weeks before Bailey's escape"; that the chief medical officer at New Jail testified that there was no evidence that Walker was an epileptic; and that Cooley testified "that he left the jail by himself and that he did not know 
them to be, are not a defense to the charges in this case, nor justification for the commission of the offense of escape." " 8 In addition, the trial court refused to allow the jury to consider a defense of duress, for none of the defendants had attempted to surrender after the escape, ${ }^{7}$ and had thus failed to meet a prerequisite to the assertion of the duress defense. All three defendants were found guilty as charged under the federal escape statute.

On appeal, a divided United States Court of Appeals for the District of Columbia, in an opinion by Chief Judge J. Skelley Wright, reversed the three convictions and remanded the cases for retrial. ${ }^{8}$ The court found that prejudicial error in the district court's instruction to the jury concerning the elements of "escape" had precluded the jury from assessing evidence pertaining to the nature of the defendants' intent. ${ }^{9}$ Prejudicial error was also perceived in the trial court's imposition of a "return requirement" conditioning the assertion of the duress defense. Chief Judge Wright approved the prevailing doctrine that escape is a "continuing offense," stating that "one may commit the crime of escape, even if his original departure from custody was justified, by failing or refusing to return to custody once the justifying circumstance is no longer present." 10 This analysis sensibly assumes that justification of the original departure should not allow an escapee to remain free from incarceration indefinitely. Thus it is an "escape" if the condition that precipitated the initial departure disappears and the escapee continues to remain free. Commission of the crime of escape may therefore postdate the actual departure from prison.

This theory of escape as a continuing offense was reflected in neither the indictment ${ }^{11}$ nor the charge to the jury. ${ }^{12}$ Both re-

whether Bailey and Walker left at all." Id. 1106-08 (Wilkey, J., dissenting) (emphasis in original) (citations omitted).

6 Id. 1091 n.9 (quoting Trial Record at 773, United States v. Bailey, D.C. Crim. No. 76-735 (D.D.C. March 14, 1977), rev'd, 585 F.2d 1087 (D.C. Cir. 1978), cert. granted, 47 U.S.L.W. 3621 (U.S. 1979) (No. 78-990)).

7 Id. 1091. Walker testified that after the escape he established and maintained "a constant rapport with the FBI," although he admitted that he never turned himself in. Id. 1108 (Wilkey, J., dissenting).

$8 \mathrm{Id}$. 1105. A dissenting opinion was filed by Judge Wilkey. In an additional section of the opinion, not considered in this Comment, the court rejected the defendants' argument that they were not guilty of the federal crime of escape because they had not technically been "in the custody of the Attorney General." Id. 1104.

${ }^{9}$ Id. 1101.

10 Id. 1099-100 (emphasis in original).

11 Defendants were indicted for "fllee[ing] and escap[ing]' '[o]n or about August 26, 1976." "Id. (quoting Record at 32, United States v. Bailey, D.C. Crim. No. $76-735$ (D.D.C. March 14, 1977), rev'd, 585 F.2d 1087 (D.C. Cir. 1978), cert. granted, 47 U.S.L.W. 3621 (U.S. 1979) (No. 78-990)).

12 Id. 
ferred to an alleged crime occurring on August 26, 1976. Indeed, the trial judge's instructions, "rather than explaining a 'continuing offense' concept to the jury, emphasized the notion that the offense took place when appellants left the jail on August 26." 13 The error was that, notwithstanding his failure to explain the continuing nature of escape, the trial judge independently found the defendants guilty of an escape subsequent to the original departure, employing " $a$ theory (failure to return) that was never presented either to [defendants] or to the jury." 14 The trial court thus implicitly concluded that the precipitating condition (which initially may have caused the escape) had disappeared, and further, that the defendants had not returned, contrary to their obligation to do so. This conclusion, however, involved a finding of fact. Chief Judge Wright refused to countenance such a judicial incursion into the province of the jury, an incursion which he said undercut the defendants' constitutional right to a trial by jury. This error could have been avoided had the jury been instructed that the defense of duress must justify both the initial departure and the continued absence from prison. ${ }^{16}$

With Bailey, the District of Columbia Circuit became the first federal appellate court to suggest that the defense of duress might justify an escape that was induced by intolerable prison conditions. ${ }^{16}$

13 Id. (citation omitted).

14 Id. 1100-01 (emphasis in original).

$15 \mathrm{Id}$. 1101. See text accompanying notes 21-29 infra.

16 Confusion inevitably results when the defense of duress (or necessity) is introduced by the defendant in prison escape prosecutions. See United States v. Micklus, 581 F.2d 612, 614-15 (7th Cir. 1978); Gardner, The Defense of Necessity and the Right to Escape from Prison-A Step Towards Incarceration Free from Sexual Assault, 49 S. CAL. L. Rev. 110, 115-18 (1975); Comment, From Lovercamp to a Prisoner's Right to Escape: An Inescapable Conclusion?, 26 Burfalo L. Rev. 413 (1976). See also Note, Prison Escape: Justification as a Defense-People v. Lovercamp, 5 CAP. U. L. REv. 293, 319 (1976); Case Note, People v. Lovercamp, 9 Lox. L. REv. 466, 475 (1976); Note, California Court Holds the Defense of Necessity Available to Prison Escapees-People v. Lovercamp, 1975 U. ILL. L.F. 271, 272 [hereinafter cited as California Court].

Necessity is generally said to constitute a justificatory defense, whereas duress is considered an excuse.

To offer a justification for the act is to accept responsibility for it but to deny that, given the factual situation, it was either morally or legally wrong. ... In situations of justification the act is condoned and the actor sometimes lauded. In contrast, a defense based on excuse admits the wrongfulness of the act, but suggests, for one reason or another, that the accused is not to blame.

Gardner, supra, at 116 (footnotes omitted). See generally W. LAFAVE \& A. ScotT, HANDBOOK ON CRIMINAL LAW $\$ \$ 49-50$ (1972). Appellate courts have consistently commingled the two defenses; what is labelled "necessity" for one case is often labelled "duress" by another appellate court addressing the same set of facts. Compare People v. Lovercamp, 43 Cal. App. 3d 823, 118 Cal. Rptr. 110 (1974) (defendants escaped to avoid homosexual assault; court discussed the proffered 
Only recently has the judiciary begun to question the previously entrenched "hands off" attitude 17 toward prison administration, gradually recognizing that administrators of penal institutions cannot be absolutely relied upon to safeguard their prisoners. ${ }^{18}$ Concomitant with this more interventionist posture, has grown a recognition among various state courts that duress (or necessity) may be a legitimate defense, within carefully defined boundaries, for the escapee who has fled intolerable prison conditions. ${ }^{19}$ At the very least, Bailey is another instance of this increasing sensitivity to conditions in American prisons and to the plight of the individual prisoner-defendant.

Yet Bailey is more than one additional citation in the lengthening series of cases that accept the use of duress or necessity as affirma-

defense in terms of necessity) with People v. Harmon, 394 Mich. 625, 232 N.W.2d 187 ( I975) (defendants escaped to avoid homosexual attacks; court held that defendants could properly raise the defense of duress). The distinction is generally based upon the nature of the force that compels the actor to commit the criminal act: necessity involves non-human threats of harm (e.g., fire or storm); duress involves human threats of harm (e.g., a "gun to the head"). See California Court, supra, at 274. "This confusion [between the two concepts] can be minimized, however, by concentrating on the basic principles underlying a proffered defense and avoiding unhelpful labels such as "duress' or "necessity." "United States v. Bailey, 585 F.2d 1087, 1096-97 (D.C. Cir. 1978), cert. granted, 47 U.S.L.W. 3621 (U.S. 1979) (No. 78-990). Bailey condenses the concepts of duress and necessity under the general heading of "compulsion" defenses, which are then analyzed in terms of the two separate principles of excuse and justification. The case thereby pays heed to the rationales underlying the distinction between duress and necessity rather than to unhelpful fixed notions that focus exclusively on the source of the force. Id. 1096-98. The particular terminology used by the courts thus ultimately becomes of secondary importance in understanding the present state of the law. The important questions concern the specific conditions that permit the use of such defenses, their rationale, and their implications.

17 Compare Bethea v. Crouse, 417 F.2d 504, 505-06 (10th Cir. 1969) ("We have consistently adhered to the so-called hands off policy in matters of prison administration according to which we have said that the basic responsibility for the control and management of penal institutions, including the discipline, treatment, and care of those confined, lies with the responsible administrative agency and is not subject to judicial review unless exercised in such a manner as to constitute clear abuse or caprice upon the part of prison officials.") with People v. Harmon, 53 Mich. App. 482, 483, 220 N.W.2d 212, 213 (1974), aff'd, 394 Mich. 625, 232 N.W.2d 187 (1975) ("The time has come when we can no longer close our eyes to the growing problem of institutional gang rapes in our prison system.").

18 The persons in charge of our prisons and jails are obliged to take reasonable precautions in order to provide a place of confinement where a prisoner is safe from gang rapes and beatings by fellow inmates, safe from guard ignorance of pleas for help and safe from intentional placement into situations where an assault of one type or another is likely to result. If our prison system fails to live up to its responsibilities in this regard we should not, indirectly, countenance such a failure by precluding the presentation of a defense based on these facts.

People v. Harmon, 53 Mich. App. 482, 484, 220 N.W.2d 212, 213 (1974), aff'd, 394 Mich. 625, 232 N.W.2d 187 (1975).

19 See text accompanying notes 35-47 infra. 
tive defenses in prison-escape prosecutions. Its greatest significance, however, derives from its employment of a revised definition of criminal intent in escape prosecutions. Its holding that one element of the crime of escape is an intent to avoid confinement allows intolerable prison conditions to be used as evidence of a lack of intent to escape confinement, rather than as an affirmative defense only. This innovative approach, which serves to shift the burden of proof to the prosecution, is novel in the federal courts.

Part $\mathrm{I}$ of this Comment reviews the Bailey duress theory, considering the case in relation to prior case law to determine what, if anything, Bailey adds to the tests that various courts have developed. Part II examines the validity of the Bailey majority's intent theory, exploring its basis and focusing on the criteria that constitute the intent "test." Finally, Part III considers the future and suggests some potential effects of such an approach upon both the individual defendants and society. The Comment concludes that the Bailey decision is properly sensitive to the interests of the escapee without unjustifiably ignoring societal interests.

\section{Duress: The Relaxation of the Traditional REQUIREMENT OF IMMINENCY}

\section{A. The Return Requirement-A Jury Question}

Bailey's discussion of the duress defense focused on the narrow issue whether a jury should be allowed to consider the defense "in the absence of one of the special prerequisites some courts have imposed upon such defenses in escape cases-the requirement that an escapee turn himself in to the authorities immediately after escaping." 20 Chief Judge Wright did not question the validity of the return requirement. On the contrary, he stated that " $[\mathrm{it}]$ stands

20 United States v. Bailey, 585 F.2d 1087, 1099 (D.C. Cir. 1978), cert. granted, 47 U.S.L.W. 3621 (U.S. 1979) (No. 78-990) (footnote omitted). Further requirements limit an escapee's successful pleading of a duress defense. The seminal case of People v. Lovercamp, 43 Cal. App. 3d 823, 118 Cal. Rptr. 110 (1974), propounded five conditions:

(1) The prisoner is faced with a specific threat of death, forcible sexual attack or substantial bodily injury in the immediate future;

(2) There is no time for a complaint to the authorities or there exists a history of futile complaints which make any result from such complaints illusory;

(3) There is no time or opportunity to resort to the courts;

(4) There is no evidence of force or violence used towards prison personnel or other "innocent" persons in the escape; and

(5) The prisoner immediately reports to the proper authorities when he has attained a position of safety from the immediate threat.

Id. 831-32, $118 \mathrm{Cal}$. Rptr. at 115-16 (footnote omitted). 
for the limited and commonsense notion that a choice of evils defense to the crime of 'escape'-defined as leaving and staying away from custody-lasts only as long as the choice of evils justifies a failure to return." 21 Fulfillment of this prerequisite has long characterized the successful pleading of this affirmative defense; ${ }^{22}$ duress claims have frequently failed because escapees continued to stay away after their initial departures from custody. ${ }^{23}$ The majority did not fault the trial court's emphasis on the return requirement, but rested its holding on the absence from the indictment and from the charge to the jury of the proper theory of escape, which absence served to undermine the defendants' constitutional right to a trial by jury. ${ }^{24}$

This limited, technical holding can provide little solace to the Bailey defendants. As Judge Wilkey pointed out in dissent, "defendants admit that they did not return to custody . . . [and] defendants have adduced no evidence whatever justifying their continued absence from custody." ${ }^{25}$ Ironically, as the dissent suggests, the trial court's failure to instruct properly on the "continuing offense" nature of escape could only have served to benefit the defendants: " $[I] f$ the jury had been fully instructed on the continuing offense aspect of escape, it would have been irrational for it to have acquitted defendants, in light of the fact that defendants admitted remaining at large and failed to adduce any evidence to justify their continued absence." 28 The majority did not in any way question the firm rule, prescribed by previous cases, that an unjustified continued absence from custody bars the presentation of the duress defense. ${ }^{27}$ Nevertheless, even given the apparently nugatory effect of the remand, the dissent failed to rebut satisfactorily the majority's underlying concern: it is rightfully the province of the jury, as the

21585 F.2d at 1100 . "Choice of evils" in this context denotes the justification element of duress. See note 16 supra.

22 See, e.g., People v. Lovercamp, 43 Cal. App. 3d 823, 832, 118 Cal. Rptr. 110, 115 (1974); People v. Hocquard, 64 Mich. App. 331, 337-38, 236 N.W.2d 72, 75-76 (1975) (adopting verbatim the final four conditions set forth in Lovercamp, quoted in note 20 supra).

${ }^{23}$ See, e.g., Helton v. State, 311 So. 2d 381 (Fla. App. 1975) (court recognized the possibility of a successful necessity defense, but held against defendant because he did not return for four weeks); Matthews v. State, 288 So. 2d 712 (Miss. 1974) (court refused to allow necessity defense in part because the defendant did not immediately return to custody after the initial impending danger but, rather, continued to flee farther away).

24 See text accompanying notes 10-15 supra.

25585 F.2d at 1116 (Wilkey, J., dissenting) (emphasis in original).

26 Id. 1117 (Wilkey, J., dissenting) (emphasis in original).

27 See, e.g., cases cited in note 23 supra. 
trier of fact, and not of the trial judge, to consider whether there were circumstances justifying the defendants' failure to return.

To remand the case solely upon this failure to accord the jury its proper role, however, could be ineffectual. On remand, the trial court would properly instruct the jury that escape is a continuing offense. Unless the defendants were to present additional evidence, the court could then hold as a matter of law that the duress defense is unavailable to the defendants because they did not return to custody. ${ }^{28}$ The very case upon which the majority based its holding articulated such a procedure. ${ }^{29}$ Chief Judge Wright's technical approach to the duress defense therefore leaves the Bailey defendants in the same position as before the remand; they will remain unable to reach the jury with a duress defense on retrial unless they are able to introduce facts to explain and justify their failure to return to custody.

\section{B. The Imminency Requirement $-A$ Standard Relaxed}

Bailey's limited, technical holding obscures its real contribution to the law governing the applicability of the duress defense to escapes: a marked liberalizing of the previous, stringent requirement of an imminent danger to the prisoner. Its brief suggestion that there might have been sufficient imminent danger to these escapees to justify a duress defense and its silence on other requisite aspects of the defense signal an approach that is more flexible than the doctrine reflected in earlier cases.

Until quite recently ${ }^{30}$ the judiciary inexorably applied a strict requirement of "imminent and impending danger," 31 sometimes

28 "[T]he majority concedes that if the court had instructed the jury fully as to the 'continuing offense' aspect of escape, then it could properly have held as a matter of law that the duress defense was unavailable and thereby have precluded jury consideration of the defense." 585 F.2d at 1117 (Wilkey, J., dissenting) (emphasis in original). The majority made no such concession, at least not explicitly. But see note 29 infra \& accompanying text.

29 United States v. Michelson, 559 F.2d 567 (9th Cir. 1977). "Therefore, when an escapee fails to submit to proper authorities, the asserted duress defense must be rejected because as a matter of law it does not negate the continued absence from custody." Id. 570 (emphasis added). "[Defendant's] failure to report to the proper authorities during his nearly two years of freedom following his escape . . . precludes jury consideration of the asserted duress defense." Id. 571 .

30 See note 42 infra.

31 United States v. Boomer, 571 F.2d 543 (10th Cir. 1978); State v. Milum, 213 Kan. 581, 583, 516 P.2d 984, 986 (1973) ("It is apparent that the threats . . . were made on several different occasions and thus could not have met the statutory requirement of imminence."); Pittman v. Commonwealth, 512 S.W.2d 488, 490 (Ky. 1974); State v. Green, 470 S.W.2d 565 (Mo. 1971) (en banc), cert. denied, 405 U.S. 1073 (1972). 
with shockingly harsh results. ${ }^{32}$ This hard line limited successful defenses to escape and restricted judicial review of prison conditions. ${ }^{33}$ Some later cases, however, have tempered this standard. In People v. Harmon, ${ }^{34}$ the escapee had been attacked on two separate occasions by a group of inmates demanding homosexual favors. When the defendant refused, he was beaten; when he was threatened a third time, he escaped..$^{35}$ At trial, the defendant raised the duress defense. ${ }^{36}$ The court rejected a "hands off" approach ${ }^{37}$ and held that the jury must be allowed to consider such a defense. ${ }^{38}$ In elucidating the conditions that delimit duress, the court conceded that a generalized fear of homosexual attacks would not suffice, ${ }^{39}$ but it did not adopt the extreme view of the earlier courts.40 "[T] of whether the alleged danger was immediate or imminent is, in all but the clearest cases, to be decided by the trier of fact taking into consideration all the surrounding circumstances, including the defendant's opportunity and ability to avoid the threatened harm." 41 Later cases have approved the Harmon result, rejecting the earlier harsh approach. ${ }^{42}$ There remained, however, the prerequisite that

32 " 'Compulsion which will excuse," it has been said, 'must be present, imminent, and impending, and of such a nature as to induce a well-grounded apprehension of death or great bodily harm if the act is not done." "R. PERKIns, Crmmnar Law 054 ( $2 \mathrm{~d}$ ed. 1969) (citations omitted). Some cases have blindly followed this precept of general criminal law, even though the crime of prison escape raises unique problems that demand an alternative approach. See text accompanying notes 51-59 infra. In State v. Green, 470 S.W.2d 565 (Mo. 1971) (en banc), cert. denied, 405 U.S. 1072 (1972), the defendant was forced to submit to sodomy on two separate occasions. When he was threatened for a third time, he complained to prison officials, who told him to "fight it out, submit to the assaults, or go over the fence." Defendant chose the last option. At his trial, he attempted to raise the defense of duress. The court responded: "This is not a case where defendant escaped while being closely pursued by those who sought by threat of death or bodily harm to have him submit to sodomy." Id. 568. State v. Green was questioned in a later case in the same jurisdiction. State v. Haddix, 566 S.W.2d 266 (Mo. Ct. App. 1978).

33 See, e.g., State v. Palmer, 45 Del. 308, 72 A.2d 442 (Ct. Gen. Sess. 1950); People v. Noble, 18 Mich. App. 300, 303, 170 N.W.2d 916, 918 (1969). See note 17 supra.

3453 Mich. App. 482, 220 N.W.2d 212 (1974), affd, 394 Mich. 625, 232 N.W.2d 187 (1975).

$35 I d .486,220$ N.W.2d at 214.

36 Id.

37 See note 17 supra.

3853 Mich. App. at 485, 220 N.W.2d at 214.

39 Id.

40 See note 31 supra.

4153 Mich. App. at 485-86, 220 N.W.2d at 214.

42 People v. Lovercamp, 43 Cal. App. 3d 823, 118 Cal. Rptr. 110 (1974), stated that in order to establish a duress defense, the defendant must, inter alia, "[be] faced with a specific threat of death, forcible sexual attack or substantial bodily injury in the immediate future." Id. 831, $118 \mathrm{Cal}$. Rptr. at 115. See note 20 supra. Lovercamp did not specify the time interval required between the last threat of attack and the escape itself. The court did, however, clearly reject the approach 
the specific threat be closely related in time to the escape.43 "A threat of future injury is not enough." " 44

The Bailey decision goes beyond even these liberalizing cases. The threat faced by the Bailey defendants as a result of the alleged intolerable prison conditions was neither imminent nor impending. There was no evidence that the alleged fires had been set on the day of the escape; ${ }^{45}$ there had been no recent instances of guard

of State v. Green, 470 S.W.2d 565 (Mo. 1971) (en banc), cert. denied, 405 U.S. 1072 (1972), described in note 32 supra, summarizing Green to exemplify the judicial insensitivity that marked earlier cases. Lovercamp accordingly did not require the defendant to delay his escape until his attackers were upon him.

Subsequent state court cases in various jurisdictions have further modified the imminency requirement. See, e.g., People v. Hocquard, 64 Mich. App. 331, 236 N.W.2d 72 (1975). In People v. Unger, 66 ml. 2d 333, 362 N.E.2d 319 (1977), the state argued that all five Lovercamp conditions, quoted in note 20 supra, must be met before the defendant could establish his duress defense. The Illinois Supreme Court rejected such a rigid approach:

We agree with the State and with the court in Lovercamp that [these conditions] are relevant factors to be used in assessing claims of necessity. We cannot say, however, that the existence of each condition is, as a matter of law, necessary to establish a meritorious necessity defense.

. . The absence of one of the Lovercamp preconditions does not alone disprove the claim of necessity and should not, therefore, automatically preclude an instruction on the defense.

Id. 342-43, 362 N.E.2d at 323.

The Bailey dissent would adhere to the harsh rule expressed in the earlier cases: "If the danger threatened is not immediate, the defense is not available [citing State v. Green, 470 S.W.2d 565 (Mo. 1971) (en banc), cert. denied, 405 U.S. 1072 (1972), discussed in note 32 supra]. The defense is reserved for backto-the-wall situations. This requirement has been adopted by every court that has considered the availability of the defense in escape cases." United States v. Bailey, 585 F.2d 1087, 1112 (D.C. Cir. 1978) (Wilkey, J., dissenting) (emphasis in original), cert. granted, 47 U.S.L.W. 3621 (U.S. 1979) (No. 78-990). In this instance the dissent was clearly incorrect, for an Illinois court had recently bluntly rejected such a requirement in People v. Unger, 33 Ill. App. 3d 770, 338 N.E.2d 442 (1975), aff'd, 66 III. 2 d 333, 362 N.E.2d 319 (1977). "We do not believe that a 'gun to the head immediacy' is essential to establish either compulsion or necessity. To require that a prisoner be immediately pursued by armed inmates is unrealistic if this is made a condition to justify escape to save a prisoner's life." Id. 775, 338 N.E.2d at 446. Even the leading case of People v. Harmon, 53 Mich. App. 482, 220 N.W.2d 212 (1974), aff'd, 394 Mich. 625, 232 N.W.2d 187 (1975) (defendant escaped 24 hours after a confrontation in which he was threatened with death) was not as harsh as the Bailey dissent implies, as it did not involve a "gun-to-the-head" circumstance: "[W] circumstances of each case." 394 Mich. at 626, 232 N.W.2d at 188 (quoting People v. Richter, 54 Mich. App. 598, 221 N.W.2d 429 (1974)). But see People v. Condley, 69 Cal. App. 3d 999, 138 Cal. Rptr. 515, cert. denied, 434 U.S. 988 (1977); State v. Milum, 213 Kan. 432, 516 P.2d 984 (1973); State v. Jones, 2 Kan. App. 2d 220, 577 P.2d 357 (1978).

43 See cases cited in note 42 supra.

44 People v. Hocquard, 64 Mich. App. 331, 337, 236 N.W.2d 72, 75 (1975) (quoting People v. Merhige, 212 Mich. 601, 180 N.W. 418 (1920)).

45 United States v. Bailey, 585 F.2d 1087, 1106 (D.C. Cir. 1978) (Wilkey, J., dissenting), cert. granted, 47 U.S.L.W. 3621 (U.S. 1979) (No. 78-990). 
brutality directed against any of the defendants; ${ }^{46}$ and the complaint of inadequate medical care was principally advanced only by defendant Walker. ${ }^{47}$ There was simply no threat that they "would be dead before the evening [or even the week] was out." 48

Judge Wilkey, in dissent, objected vehemently to this extension of duress to general and protracted fears, challenging the majority "to cite one case, federal or state, in which claims of this type have been deemed sufficient to raise a duress defense." 49 Such cases do not in fact exist. Indeed, the Bailey decision does not articulate or explain a new test of imminence. The fact that the case was remanded, however, suggests that intolerable prison conditions of the sort alleged by the defendants might be sufficient to establish a duress defense. The court's only statement regarding the question of imminent and immediate danger was confined to a footnote that offered a rationale for the relaxation of the immediacy requirement in the extraordinary situation of prison escapes:

The dissent's narrow insistence on threats of "immediate" harm as an absolute prerequisite for the choice of evils defense seems particularly inappropriate in escape cases, where a possibility for escape (especially nonviolent escape) is not likely to remain available until a substantial threat becomes "immediate" in the narrow sense urged by the dissent. ${ }^{50}$

Although the court was unclear in its relaxation of the imminency requirement, such a relaxation does reflect a realistic understanding of prison conditions. In prison, the threat of a "future injury" ${ }^{51}$ can instill fear equally as intense as that created by more immediate, specific threats. Confined inmates must wait helplessly, hoping that the threatened harm (whether a suffocating fire or a homosexual assault) does not materialize. ${ }^{52}$ Under these circum-

$46 \mathrm{Id}$. 1107. In Bailey's case a fellow inmate did testify that "he had received a beating by one of the guards who then told him to deliver a message to defendant Bailey to the effect that the guards were going to kill him and beat him for testifying in a particular court case." Id. (footnote omitted). Even this threat, however, was not closely related in time to the escape.

$47 \mathrm{Id}$.

48 People v. Unger, 33 IIl. App. 3d 770, 775, 338 N.E.2d 442, 446 (1975), affd, 66 Ill. 2d 333, 362 N.E.2d 319 (1977).

49585 F.2d at 1117 (Wilkey, J., dissenting) (emphasis in original).

50 Id. 1099 n.39.

51 See text accompanying note 44 supra.

$52 \mathrm{~A}$ prisoner may be threatened by a fellow inmate who tells him that he is going to be attacked, or by fires that periodically break out in his cellblock, causing suffocating smoke. Although any one particular fire may not threaten his present safety, it may create a reasonable ongoing apprehension that future fires will be more dangerous. 
stances, the differences between "general" threats and "specific" threats become meaningless; the nature of the fear produced by "generalized" fears is quite similar to that produced in the "specific threat" situation. The idea of "immediate danger" is also less relevant in prisons. The prisoner cannot evaluate his degree of vulnerability as can nonprisoners; in addition, prisoners have a restricted ability to respond to threats. ${ }^{53}$

Given the nature of the prison environment, the dissent's call for an immediate danger as a prerequisite for assertion of the duress defense demands an unrealistic degree of self-control by prisoners. Although some recent cases are more sensitive to actual prison conditions, ${ }^{54}$ their demand for a "present injury" is similarly implausible in some instances. A frightened inmate should not be required to wait passively until his general fears (that he could be next) ripen into specific fears (that he will be next) and then, in turn, until the danger itself is "present." Because prisoners are not in a position to wait until the last minute, ${ }^{55}$ the test of imminency should be an attenuated one-the escape must be closely related in

53 If the prisoner must delay his attempt until the last moment, it will then be almost impossible to escape the threatened harm, for his attackers are likely to overpower him. See State v. Green, 470 S.W.2d 565, 570 (Mo. 1971) (en banc) (Seiler, J., dissenting), cert. denied, 405 U.S. 1072 (1972) ("If escape were to save [the defendant], it had to be made earlier than the last minute."). In almost all of the reported cases that have allowed the defense, the defendant escaped after the threat but before the actual assault. People v. Luther, 394 Mich. 619, 232 N.W.2d 184 (1975), is a startling exception. Six assailants made homosexual demands of defendant; when he refused he was assaulted and "literally chased off the [prison] grounds." Id. 621, 232 N.W.2d at 186. This usual timing pattern is not surprising, as one of the policies underlying the availability of the duress defense to escapees is concern for the personal security of the prisoner. The requirements of the defense should therefore be attuned to this principle. It is anomalous, then, to require the prisoner to wait until his assailants arrive, when flight from the impending assault will be hopeless.

The closed nature of prison society exacerbates tensions, causing threats to remain "in the air" as continually lurking possibilities. See Note, Duress and the Prison Escape: A New Use for an Old Defense, 45 S. Car. L. Rev. 1062, 1074 (1972). Furthermore, the prisoner who voiced the threat is encountered daily in a setting where violence is commonplace. In such close quarters he cannot be avoided. Moreover,

the availability of weapons and the sudden and often senseless nature of attacks within the prison may create in the threatened inmate an ongoing apprehension which will linger far beyond the moment of the actual threat. ... [The] chance that the assailant will appear at any moment and attack is a constantly reinforced possibility.

Id. 1075 (footnote omitted). See also Note, Availability of the Duress Defense in Prison Escapes: People v. Lovercamp, 12 Wake Fonest L. REv. 1102, 1112 (1976) [hereinafter cited as Availability of the Duress Defense]. Possibilities of escape are infrequent and cannot be discriminately chosen to match the threatened attack. See id. 1106.

54 See cases cited in note 42 supra.

55 See note 53 supra. 
time to the threat-rather than one of strict imminency. ${ }^{58}$ In each case, whether the defendant has successfully met the test of imminence should be determined by the trier of fact. The time elapsed between the threat and the anticipated harm should be considered in light of two factors: the quality of the threat and the nature of the prison conditions. In some instances a threat may be especially dangerous (even when a day or two has already elapsed) if violence is a commonplace occurrence at that prison, thereby magnifying even the most minute threat into potential harm. On the other hand, some significant threats may vanish within hours if made in an atmosphere where violence is rare and the prison administration is highly sensitive to its prisoners' safety.

This relaxed notion of the duress defense, however, should not give a free rein to any inmate who escapes and then attempts to excuse his behavior because he can point to intolerable conditions within the prison. Duress would remain limited by the further requirement that the inmate convince the trier of fact that such threatened intolerable conditions would have impinged upon his personal security. Such personalized "impingement" was present in Bailey; the defendants, therefore, should have been permitted to present their defense to the trier of fact. But had the present defendants merely alleged that other inmates were targets of guard brutality, that other inmates were denied proper medical treatment, and that other inmates suffered from fires and smoke, it would have been unreasonable to argue that duress existed because of the creation of general fears. On the contrary, the inmate must posit a close connection; he must be able to point to intolerable conditions that directly affected him.

Bailey itself does not propose this, or any other test. Indeed, the entire issue of imminency is treated summarily. ${ }^{5 t}$ Nevertheless, the proposed liberalized test suggested by Bailey and explored in this Comment would evaluate more justly the plight of the individual defendant who is unable to distinguish between levels of fear based on the relative imminence of some future harm. ${ }^{58}$ As a

56 See Availability of the Duress Defense, supra note 53, at 1107.

57 See text accompanying note 50 supra.

58 The applicability of the duress defense requires a consideration of other factors in addition to imminency. Indeed, Bailey recognized the relevance of the five conditions required in People v. Lovercamp, 43 Cal. App. 3d 823, $118 \mathrm{Cal}$. Rptr. 110 (1974), quoted in note 20 supra, but did not require that each be met before the defendant can introduce his duress defense.

The court ... holds that, at least when a defendant, as in this case, introduces substantial evidence of extreme conditions, the jury is not absolutely prohibited from considering such evidence merely because certain inflexible 
California court stated: "In a humane society some attention must be given to the individual dilemma." 59

\section{Intent: The New Test Articulated}

In addition to relaxing the imminency requirement, the District of Columbia Circuit in Bailey also rejected the trial court's holding that the crime of escape requires only general, rather than specific, intent. ${ }^{60}$ As a result, the defendant in federal prison escape prosecutions will not be forced to rely solely on duress and mistake defenses in claiming that his escape was "involuntary." $\mathrm{He}$ now has a second option: in the appropriate circumstances, ${ }^{61}$ when the prosecution's evidence of an intentional escape is based solely on the inferences that can be drawn from departure from prison without permission, the defendant can present evidence rebutting this inference. He can thereby force the prosecution to present proof of the presence of an actual intent to avoid confinement as an element of the crime. ${ }^{62}$ This new, added requirement of proof has far-reaching implications for future escape prosecutions. ${ }^{63}$

\section{A. Intent as an Element of Escape}

Escape was traditionally considered a "general intent" crime. ${ }^{64}$ "No state of mind is required for guilt of escape other than the

prerequisites are not satisfied. In the court's view, the factors represented by the prerequisites are the most significant considerations, but none of the prerequisites by itself is necessarily determinative. Once the defendant has presented a threshold amount of evidence, that evidence is to be considered by a properly instructed jury.

585 F.2d at 1096 n.28. The test articulated in this Comment relates only to the immediacy requirement. Although Bailey indicated that the other requirements for the duress defense are Hexible, it did not elaborate its reasons, nor did it suggest what mitigating factors should be considered. The present discussion has therefore centered exclusively on the requirement of immediacy, for here the case presents at least some attempt at a rationale. See text accompanying note 50 supra. (1974).

59 People v. Lovercamp, 43 Cal. App. 3d 823, 827, 118 Cal. Rptr. 110, 112

00585 F.2d at 1094-95, 1101.

61 See text accompanying notes 99-107 infra.

$62585 \mathrm{~F} .2 \mathrm{~d}$ at 1093. This approach is novel in federal law, even though the language was the same in United States v. Nix, 501 F.2d 516 (7th Cir. 1974), because in Bailey, a federal court for the first time suggested that a prisoner who seeks only to avoid intolerable conditions has not displayed the requisite intent to avoid confinement, and therefore is innocent of the charge of escape under 18 U.S.C. $\$ 751$ (1976). 585 F.2d at 1093 n.17. For state court interpretations see text accompanying notes 69-75 infra.

63 See part III infra.

64 "[A] great deal of unnecessary confusion has been generated by the use of ill-defined terms and concepts such as 'specific' and 'general' intent." United States 
intent to go beyond permitted limits ...." 65 Some courts, however, have recognized that there must at least be an intent to leave lawful custody ${ }^{66}$ For example, in several recent cases involving intoxication defenses, if some higher level of intent were not an element of the crime, the drunken prisoner who stumbled across prison boundaries could have been found guilty of escape without further inquiry. ${ }^{67}$ But, even though the strict general intent standard has been somewhat relaxed, no federal court has yet held that an escapee whose sole intent was to avoid intolerable prison conditions lacked the necessary criminal intent. ${ }^{68}$

v. Bailey, 585 F.2d 1087, 1092 (D.C. Cir. 1978), cert. granted, 47 U.S.L.W. 3621 (U.S. 1979) (No. 78-990) (footnote omitted). A federal court approved one definition of the difference between the two types of intent that had been given as an instruction to a jury: "Specific intent, as the term itself suggests, requires more than a mere general intent to engage in certain conduct. A person who knowingly does an act which the law forbids, or knowingly fails to do an act which the law requires, intending with evil motive or bad purpose either to disobey or disregard the law, may be found to act with specific intent." Rivers v. United States, 368 F.2d 362, 364 (9th Cir. 1966), cited in United States v. Nix, 501 F.2d 516, 517 n.2 (7th Cir. 1974).

65 R. PERkTns, supra note 32, at 504 (citing State v. Clark, 32 Nev. 145, 104 P.2d 593 (1909), which involved the sufficiency of an indictment for attempted escape). Many courts have followed this rule. See, e.g., People v. Haskins, 177 Cal. App. 2d 84, 2 Cal. Rptr. 34 (1960) (holding that under California's escape statute, only general intent to do the act need be shown, and that voluntary intoxication is therefore no defense); Wiggins v. State, 194 Ind. 118, 14I N.E. 56 (1923) (affirming convictions on the basis that intent can be inferred from the fact of defendants' departure of their own volition); State v. Wharff, 257 Iowa 871, 134 N.W.2d 922 (1965) (holding that under the Iowa statute neither guilty knowledge nor criminal intent need be proved). Cf. United States v. Locke, 425 F.2d 313, 315 (5th Cir. 1970) (holding that a statement signed by defendant upon incarceration, by which he acknowledged that leaving without permission or failure to return "shall be deemed an escape," was properly admitted, thus suggesting that improper absence alone constitutes escape).

66 See, e.g., People v. Weiseman, 280 N.Y. 385, 21 N.E.2d 362 (1939) (when a prisoner was allowed to leave a detention area, state must prove prisoner knew discharge was illegal; escape charge dismissed because court guards could provide no evidence on circumstances of departure, while defendant testified that he was told to leave). Cf. Coleman v. State, 83 Tex Crim. 472, 204 S.W. 332 (1918) (defendant who had been released to an employer under a convict bond arrangement was innocent of escape although he left that employer's premises, since the departure was made because he had nothing to eat, had not been informed of arrangements for food, and later informed the employer of his whereabouts).

67 See, e.g., Mills v. United States, 193 F.2d 174 (5th Cir. 1951), cert. denied, 343 U.S. 969 (1952) (holding that the lower court properly admitted defendant's claim that a drug overdose rendered him incapable of knowingly intending to escape, but agreeing that a jury could disbelieve the claim and on the evidence convict defendant of escape); People v. Dolatowski, 94 Ill. App. 2d 434, 237 N.E.2d 553 (1968) (reversing defendant's conviction because the trial court improperly instructed the jury on an intoxication defense, placing too great a burden of proof on the defendant). Cf. Chandler v. United States, 378 F.2d 906 (9th Cir. 1967) (affirming convictions of defendants, who, although arguably lacking in the necessary intent to escape at the time of their departure because of intoxication, demonstrated the requisite intent by later actions, including theft of a vehicle).

68 United States v. Bailey, 585 F.2d 1087, 1129-30 (D.C. Cir. 1978) (Wilkey, J., dissenting), cert. granted, 47 U.S.L.W. 3621 (U.S. 1979) (No. 78-990). 


\section{State Court Decisions Presaging Bailey}

State courts have traditionally followed the rule that general prison conditions, no matter how bad, offer no excuse for escape. ${ }^{63}$ Those courts have recognized, however, that under certain circumstances the "escapee" has not committed the crime of escape, but such cases have been restricted to those instances in which the prisoner was forced to leave under duress, ${ }^{70}$ was mistaken about his right to leave, ${ }^{71}$ or was so intoxicated as to be incapable of knowing the consequences of his actions. ${ }^{72}$

In contrast to this traditional rule, Florida permits consideration of the particular prisoner's decision to escape. If he did so only to avoid a particularly intolerable condition, the requisite intent is lacking. Two cases illustrate the Florida rule. In Bavero v. State, ${ }^{73}$ an escape conviction was reversed when an inmate fled to seek recognition of and assistance for a severe medical condition. Upon transfer to a new institution, the inmate's medical classification had been upgraded and he was declared fit for hard labor. Actually incapable of doing such work because of a life-long asthmatic condition, he resisted, and was consequently placed in a device called "the box" for a number of hours and told that he would be left there permanently if he resisted again. Repeated attempts to seek review of his work designation or further examination of his condition were unsuccessful. He could work only by using an inhaler several times hourly, although he had been previously told that he would suffer a heart attack if it were used more than six times daily. Finally, he escaped. When captured a few

69 See, e.g., State v. Alberigo, 109 Ariz. 294, 508 P.2d 1156 (1973) (threats by officers to harm defendant cannot justify escape); Matthews v. State, 288 So. $2 \mathrm{~d} 712$ (Miss. 1974) (threats by guards to kill defendants offered no basis for a defense); State v. Green, 470 S.W.2d 565 (Mo. 1971) (en banc), cert. denied, 405 U.S. 1073 (1972) (prior homosexual attacks and threats of future attacks do not constitute a basis for a defense when the defendant had several hours in which to report the threats). For a more extensive compilation of such cases, see State v. Alberigo, 109 Ariz. 294, 297, 508 P.2d 1156, 1159 (1973).

70 See, e.g., People v. Lovercamp, 43 Cal. App. $3 \mathrm{~d} 823,118 \mathrm{Cal}$. Rptr. 110 (1974); People v. Harmon, 394 Mich. 625, 232 N.W.2d 187 (1975). See generally the discussion of the duress defense in Part I supra.

i1 See, e.g., People v. Weiseman, 280 N.Y. 385, 21 N.E.2d 362 (1939) (when a prisoner was allowed to leave a detention area, state must prove prisoner knew discharge was illegal; escape charge dismissed because court guards could provide no evidence on circumstances of departure, while defendant testified that he was told to leave); State v. Pace, 192 N.C. 780,136 S.E. 11 (1926) (defendant, who allegedly assisted in posting a fraudulent bond to secure release of a prisoner, held innocent of assisting escape because prisoner was unaware bond was fraudulent).

72 See cases cited in note 67 supra.

73347 So. 2 d 781 (Fla. Dist. Ct. App. 1977). 
hours later, he claimed he was only seeking help from federal authorities. The court, noting that the defendant had since been reclassified and given lighter work assignments, reversed a conviction for escape because the trial court had disallowed introduction of defendant's rationale for the departure.

Another Florida court similarly reversed an escape conviction in Lewis $v$. State, ${ }^{74}$ stating that the trial court should have admitted defendant's evidence relevant to his claim that he lacked the requisite intent to escape because his sole reason for leaving prison was to contact a judge to secure protection from sexual assaults. The defendant had argued that the fact that he had fled to a radio tower on the roof of the prison, while another inmate, escaping at the same time, had left the prison entirely, was evidence that he was avoiding a condition of confinement, not confinement itself. The appellate court held that the theory and evidence suggesting a lack of intent should have been admitted.

Thus state courts, particularly those in Florida, have begun to require more than mere general intent in escape prosecutions. ${ }^{75}$ The concerns that led to these state decisions parallel those that resulted in the Bailey decision.

\section{Federal Precedent for the Bailey Rule: The Applicability of United States $v$. Nix}

According to the Bailey court, United States $v$. Nix ${ }^{76}$ represents an abrupt break with the traditional federal rule that prison conditions are irrelevant to intent determinations. ${ }^{77}$ If this analysis is sound, neither the escapee who is intoxicated nor the escapee who is avoiding intolerable prison conditions (provided that such avoidance is the only reason for his flight) are guilty of the federal charge of escape; in each case the requisite element of criminal intent is absent. Nix eschewed the labels of "general" and "specific" intent, inquiring instead into "what constitutes the 'escape' element of the crime" 78 and concluding that "escape [is] a voluntary departure

74318 So. 2 d 529 (Fla. Dist. Ct. App. 1975), cert. denied, 334 So. 2d 608 (Fla. 1976).

75 See Coleman v. State, 83 Tex. Crim. 472, 204 S.W. 332 (1918) (prisoner bonded to one employer who left because of lack of food found innocent of escape even though a general intent could be found and there was no threat rising to the level of duress). See also People v. Field, 28 Mich. App. 476, 184 N.W.2d 551 (1970) (burden is on the state to prove that defendant did not leave prison under duress).

76501 F.2d 516 (7th Cir. 1974).

77585 F.2d at 1092-93.

78501 F.2d at 518. 
from custody with an intent to avoid confinement." 79 In defining the elements of federal escape, Nix relied upon earlier mistake cases in which the escapee departed from prison either because he was intoxicated ${ }^{80}$ or because he was justifiably mistaken, leaving prison honestly believing that he had been set free by the law. ${ }^{81}$ But Nix in no way suggested that a prisoner fleeing only the presence of intolerable conditions has not exhibited the criminal intent required in escape prosecutions. Nevertheless, Bailey relied upon Nix in adopting this proposition. ${ }^{82}$ In order to determine whether the application of the Nix rule to Bailey situations is justifiable, it is necessary to examine the underlying rationales for the intent requirement.

The Nix court identified two bases for the necessity of showing intent in escape prosecutions:

The courts have been close to unanimous in requiring intent to escape probably for two reasons. The first is "the desire to have one human element of "blameworthiness' as a basis for punishment." The other reason is the knowledge that a prisoner who has no intent to escapebecause he is grossly intoxicated, or thinks his jailer has told him to leave, or mistakes the boundaries of his confinement, or has a gun held to his head by another inmateis not likely to endanger society, as a willful escapee is. ${ }^{83}$

These reasons were acknowledged in Bailey, ${ }^{84}$ but the court failed to apply them to situations in which allegedly intolerable conditions precipitated the escape. The Bailey court's reliance on Nix is justifiable only if these rationales remain valid when intolerable prison conditions, not mistake, are the "cause" of the escape. Even if the Nix reasons are not appropriate, there may be other justifications for the Bailey intent rule, in which case the court should have spelled them out, rather than relying on Nix.

\section{a. Blameworthiness}

Initially, the "blameworthiness" rationale appears to be inapposite in the case of an escape from intolerable conditions. When the intoxicated prisoner awakes, he will realize his error and return

79 Id. 519.

80 See cases cited in note 67 supra.

81 See cases cited in note 71 supra.

82585 F.2d at 1092-93.

$83501 \mathrm{~F} .2 \mathrm{~d}$ at 519 (footnote omitted).

84585 F.2d at 1092-93. 
to custody; had he been sober he would not have attempted to depart. Similarly, when the prisoner learns that his jailer was mistaken in allowing him to leave, he will return to custody. ${ }^{85}$ In a very real sense, such escapees are not responsible for their actions. Therefore, punishing them would have no deterrent effect; they are not "blameworthy." 86 By contrast, the prisoner who escapes solely to avoid intolerable conditions intensely desires to leave, for he believes that escape offers his sole opportunity to avoid threatened harm. ${ }^{87}$ His act results from a conscious decision to risk apprehension and punishment because of the magnitude of the harm threatening him. Theoretically, at least, the deterrent effect of punishment in this instance would be relatively high. The greater the potential risk, the less likely is the threatened prisoner to chance flight.

A closer examination of the situation of a prisoner fleeing intolerable conditions, however, reveals a compelling parallel with situations that have been said to present a lack of intent to escape..$^{88}$ The threatened prisoner, like the intoxicated or mistaken prisoner, does not escape because he would rather be free than incarcerated. Although that may be a factor, as in the mistake cases, he escapes primarily to be free from the intolerable conditions that pose dangers to his personal security. ${ }^{89}$ Such action is difficult to characterize as "blameworthy." A jury might excuse such behavior if it were to consider simultaneously the conditions that motivated the defendant to flee. It is precisely in this instance that other cases interpose duress as a legitimate affirmative defense; the defendant may either lack the necessary subjective state, or mens rea, to be held

85 This discussion assumes that there was no intent to escape confinement prior to the intoxication or mistake of the official.

80 If such escapees did not in fact return to prison after they sobered or learned of the mistake, an intent to escape would be evidenced. Formation of such an intent, however, would post-date the actual departure. At that earlier point in time an intent to escape may have been absent. For instance, an intoxicated escapee may wake up, discover his freedom, and then decide to remain free. Criminal intent is formed only at this point, and not when he stumbles across the prison boundaries. Paradoxically, an intent to escape may be absent when the prisoner departs from prison; an intent to escape may surface when a prisoner has already been free for some period of time. See, e.g., Chandler v. United States, 378 F.2d 906 (9th Cir. 1967) (while intent was arguably absent at time of departure, it was demonstrated by later actions, including auto theft).

87 This discussion assumes that the prisoner has exhausted the available legal alternatives, such as resort to the courts and complaints to the prison authorities.

$88 \mathrm{See}$, for example, the hypothetical situations described in the context of the escapee who will not endanger society in United States v. Nix, 501 F.2d 516, 519 (7th Cir. 1974), quoted at text accompanying note 83 supra.

89 See text accompanying notes $99-123$ infra. 
responsible for his behavior, ${ }^{90}$ or, even in jurisdictions which require only a general intent to escape, ${ }^{91}$ the defendant's actions may be justified. Such cases realistically recognize that free will can be encumbered by external constraints. Therefore, it is extremely problematical to place blame on the prisoner who flees from intolerable conditions. The criminal law excuses the prisoner who is pushed across the prison grounds with a cocked gun at his head; similarly, it should excuse the Bailey-type defendant, who, had he not been subjected to threats to his personal security, would not have escaped, assuming there is no contrary evidence. ${ }^{92}$ Thus the "blameworthiness" rationale is applicable in the context of an escape from intolerable prison conditions.

\section{b. Danger to Society}

The second basis identified in Nix for requiring intent as an element in escape prosecutions was that a prisoner who lacks such intent is unlikely to be a danger to society. ${ }^{93}$ This second rationale shifts the focus from the individual defendant to the societal harm he is likely to cause in attempting to attain or maintain freedom. "A prisoner who leaves his custody without an intent to escape will not use force to leave the prison nor resist capture when he is found." 94 Such a prediction is inapposite in the Bailey situation. ${ }^{95}$ If the escapee is fleeing from significant threats to his personal safety, he will probably employ every possible means to facilitate his escape. He has been threatened with serious bodily injury or even death; it is therefore unrealistic to suppose that he will shy away from force, or even violence, in effecting his escape. He is a "determined" man, 96 determined to escape from an intolerable and dangerous situation.

Thus, important distinctions can be drawn between the case of the intoxicated or mistaken escapee and the escapee fleeing due to perceived threats. The question is whether these distinctions render the Bailey court's reliance on Nix invalid. A possible solution to the

90 See cases cited in note 42 supra.

91 See notes $64-68$ supra \& accompanying text.

92 See note 86 supra.

93501 F.2d at 519.

94 Id. This rationale assumes that the intoxicated escapee with no intent to avoid confinement will meekly surrender himself to the authorities when he sobers. At the least, such an escapee is unlikely to resist recapture or "rob a store to facilitate his escape." Id.

95 This prediction is equally inapposite, however, to the Nix hypothetical of the prisoner with a gun to his head. See text accompanying note 83 supra.

96501 F.2d at 519. 
problem of potential violence would be to preclude the use of this "intent theory" by defendants who do in fact resort to force. This, however, would be logically inconsistent with the blameworthiness rationale. Certainly some escapees could truly intend only to flee from intolerable conditions and yet still resort to violence or force. Indeed, the most determined escapees-those who are most threatened by imminent and severe harm-will be the ones most likely to use force. A more reasonable solution would be to treat the escapees like ordinary citizens and hold them criminally liable for behavior that ordinarily would be punished. If the determined escapee steals a car, he should be charged with auto theft but not with escape if, in fact, he lacks the necessary criminal intent. ${ }^{97}$ In addition, the Nix social-danger rationale is applicable once the escapee has completely effected his escape. Although such an escapee is perhaps unlikely to return voluntarily, he did not escape to avoid confinement and is therefore not as great a social danger as a prisoner escaping to resume a criminal career. Thus Bailey's reliance on $N i x$ is justifiable, even though Bailey itself neglects the crucial task of determining whether Nix does in fact provide such support. A more serious shortcoming of the Bailey opinion, however, is that it does not attempt to resolve the problem of the violent escapee. ${ }^{88}$

\section{B. Elements of the Intent Test}

Although Bailey held that the trial court was incorrect in its finding that escape requires only general intent, agreeing with $N i x$ that intent is an element of the crime, ironically, the actual test to determine the presence or absence of the requisite criminal intent was buried in a footnote.99 Bailey first distinguished "confinement" and "non-confinement" conditions. The former comprise the "normal incidents of confinement." 100 For example, "[o]ne who leaves custody without permission to see his mother who is ill or to improve his menu . . . has an intent to avoid confinement since restricted contact with relatives and a reasonably limited choice of diet are normal incidents of confinement." 101 The majority thus recog-

97 See text accompanying notes 99-123 infra. If, however, the escapee is acting under duress, some criminal acts that may accompany his escape (e.g., fighting off a fellow inmate in order to reach the prison wall) may be excused. The duress affects both the act of escaping and concomitant acts necessary to effectuate the escape. See text accompanying notes 156-60 infra.

98 See text accompanying notes 93-97 supra. For a further discussion of this problem, see text accompanying notes 151-60 infra.

$99585 \mathrm{~F} .2 \mathrm{~d}$ at $1093 \mathrm{n.} .17$.

100 Id.

101 Id. 
nized that incarceration necessarily entails certain basic infringements of personal liberty. Conversely, if an inmate escaped confinement solely to avoid "conditions that are not normal aspects of 'confinement'-such as beating in reprisal for testimony in a trial, failure to provide essential medical care, or homosexual attacks-the intent element of the crime of escape may not be satisfied." 102

As the dissent in Bailey accurately pointed out, the trier of fact must undertake a three-part inquiry: "First, what condition or factor prompted the defendant to depart from custody? Second, was this condition a 'normal incident of confinement'? And, third, was the defendant's departure prompted 'only' by this factor or condition?" ${ }^{103}$ Although the question of intent is not a component of the defendant's defense, it is an element of the crime and must therefore be proved by the prosecution beyond a reasonable doubt; ${ }^{104}$ thus as a purely practical matter the burden of production of a lack of intent rests upon the defendant. An intent to avoid confinement may be inferred from the fact of escape; therefore, evidence that the defendant departed from the prison without permission is sufficient to meet this required showing of intent unless the defendant then submits evidence that points to an intent to avoid intolerable conditions, not confinement. ${ }^{105}$ Thereafter the prosecutor can rebut the evidence, exposing inconsistencies in defendant's evidence and presenting new evidence demonstrating that the defendant actually intended to avoid confinement.

The prosecutor can offer evidence of any circumstances or behavior inconsistent with the defendant's exculpatory contentions. Depending on that evidence, a prosecutor may argue that the conditions allegedly necessitating the defendant's departure from custody were relatively mild, that alternative remedies short of escape (e.g. resort to prison authorities or the courts) were available, or that the defendant failed to return voluntarily to custody once the

102 Id. (emphasis in original). Apparently the task of deciding what constitutes such non-confinement conditions is left to the trier of fact. In most cases the answer will be self-evident:

Jurors are readily aware that a person serving a sentence for a crime is "confined"-i.e. his liberty is restricted-in certain fundamental ways. For example, he cannot leave the institution wherein he is confined, he cannot come and go as he pleases, his daily schedule is subject to various controls, his privacy is substantially curtailed, and he is subject to strict discipline. Id.

103 Id. 1129 (Wilkey, J., dissenting).

104 Id. 1094 n.18.

105 Id. 1094 n.19. 
conditions allegedly motivating the escape no longer threatened him. ${ }^{106}$

These standards are not "inflexible requirements," but they are germane to the jury's inquiry. ${ }^{107}$ Thus the prosecutor can argue that the defendant's failure to meet certain minimal standards of conduct, ${ }^{108}$ such as attempting to make use of prison or judicial remedies to correct the intolerable conditions before fleeing, precludes his attempt to claim a lack of criminal intent. This appears at first to be logically inconsistent with the intent rationale. Consider the situation of an escapee who honestly believed that his life was threatened by intolerable prison conditions, that such conditions actually existed, and that the jury would conclude that these conditions were "non-confinement conditions." 109 If the jury were properly to focus its inquiry upon the presence or absence of criminal intent, it should make no difference that this defendant did not first resort to the prison authorities or the courts, for the jury's inquiry into criminal intent is necessarily subjective. ${ }^{110}$ The jury should not ask what a reasonable person would have felt or done if he were threatened under similar circumstances, but should examine what this particular defendant felt: did this threat cause him to leave prison? Even though the intent inquiry is subjective, consideration of these standards of conduct is necessary to the intent inquiry. The trier of fact is faced with the difficult task of determining the defendant's psychological motivation for escaping. The defendant's actions, as well as his testimony, are helpful in making this determination. The failure of the defendant to make use of readily available and reasonably efficacious alternatives to escape, for example, suggests that his real motive was avoidance of confinement.

There are additional reasons to give weight to objective standards. Because prison escapes have potentially disruptive and chaotic effects upon society, public policy considerations cannot be ignored. Such considerations support the introduction of a further objective

106 Id. 1094.

107 Id. 1096 n.28. See People v. Unger, 66 Ill. 2d 333, 342, 362 N.E.2d 319, 323 (1977). Five absolute preconditions to the defense of duress were stated in People v. Lovercamp, 43 Cal. App. 3d 823, 118 Cal. Rptr. 110 (1974). See note 20 stupra. A defendant tried under the Bailey intent rule, unlike a defendant tried under the Lovercamp criteria, will not necessarily be found guilty as a matter of law if the five conditions are not met. But see note 42 supra.

108 Such minimal standards have also been required for the duress defense. See note 20 supra.

109 In addition, assume that the defendant escaped solely because of these confinement conditions. See text accompanying notes 113-17 infra.

110 See R. Perkons, supra note 32 , at 573-74. 
component into the intent test. The escapee's fears must be "reason. able" 111 and his response must be reasonable. Hence the jury should properly consider the defendant's failure to take advantage of available alternatives short of escape. If the jury is unable to find a satisfactory reason for defendant's omission, it may find criminal intent, even though the defendant actually may have escaped to avoid non-confinement conditions. The escape remedy is therefore restricted to those inmates who resort to it when there are no other reasonably available and effective alternatives. ${ }^{112}$

Even if the defendant successfully establishes that he was motivated to escape to avoid a non-confinement condition, ${ }^{113}$ he may still be convicted of escape under the Bailey approach. To be found innocent under the Bailey rule, the defendant must escape solely to avoid non-confinement conditions. ${ }^{114}$ This added requirement of exclusivity may create paradoxical situations. Consider the inmate who has been repeatedly attacked and has just as repeatedly complained-unsuccessfully-to prison authorities. Threatened again, he escapes to avoid this "non-confinement" condition of threats and

111 See note 102 supra \& accompanying text. The defendant's evidence of intolerable prison conditions must convince the jury that these conditions are indeed intolerable. Certain conditions, even though "nonconfinement" in nature, might not warrant escape as a response, for there is a minimal level of harm to which a condition must rise. For an analogous notion in the eighth amendment context, see Comment, Actionability of Negligence Under Section 1983 and the Eighth Amendment, 127 U. PA. L. Rev. 533 (1978).

112 Under a strict reading of the intent theory, the absence of criminal intent is certainly questionable when obvious alternatives were available to defendant but he ignored them and escaped. The trier of fact may deem his story implausible and rather believe that defendant's real intent was to escape from "confinement conditions."

113 The line between confinement and non-confinement conditions is ordinarily distinct. See text accompanying note 102 supra. But what result should follow if the escapee reacted to a mild non-confinement condition, such as a very mild beating at the hands of a fellow inmate? If the defendant successfully meets the other requirements of the intent test, will this minor non-confinement condition negate criminal intent? Bailey asserts that the defendant must introduce some threshold amount of evidence to meet the requirement of a non-confinement condition. "Since the evidence offered by [defendants] in this case was clearly 'substantial,' we need not decide the minimum threshold of evidence necessary to entitle a defendant to this instruction." 585 F.2d at 1094 n.19. Unless it is absolutely clear that nonconfinement conditions do not exist, this question should be left for the jury. "[T]he proper approach is to inform the jury of those considerations that are relevant to its deliberations, not to take the issue out of its hands." Id. 1096.

114 See text accompanying note 103 supra.

[I]f a prisoner offers evidence to show that he left confinement only to avoid conditions that are not normal aspects of "confinement" ... the intent element of the crime of escape may not be satisfied. When a defendant introduces evidence that he was subject to such "non-confinement" conditions, the crucial factual determination on the intent issue is thus whether the defendant left custody only to avoid these conditions or whether, in addition, the defendant also intended to avoid confinement.

585 F.2d at 1093 n.17 (emphasis in original). 
violence. At trial, however, the prosecutor offers evidence conclusively demonstrating that defendant also, departed to see his sick mother. The intent element of the crime is now satisfied, despite the extreme nature of this "non-confinement" condition, for defendant did not possess the sole intent to avoid non-confinement conditions. ${ }^{115}$

\section{G. Majority $v$. Dissent}

Judge Wilkey, in dissent, argued strongly against the majority's innovative intent test. He would approach the question of coercion under the sole rubric of duress. "If legally sufficient duress does not exist, then the defendant is deemed to be acting voluntarily as a matter of law." $116 \mathrm{He}$ would thus deflect the inquiry away from the individual defendant by adopting the more stringent and objective approach formulated in People v. Lovercamp. ${ }^{117}$

Ultimately, however, the disagreement between majority and dissent rests on core philosophical differences concerning "the issue of voluntariness and reflects a policy decision as to the point or stage up to which an individual under compulsion should be expected to resist pressure and act according to his own will . . . "118 In particular, the dissent maintains that a "knowing" state of mind comprises the necessary intent to establish criminal liability. 119 "There is no doubt that defendants consciously and deliberately departed from prison and that they were aware of the nature of their actions. They freely admit this, and this is all that is required to establish the 'intent' element required under 18 U.S.C. \$751." 120 Thus, according to the dissent, it is enough that the defendants knew that they were leaving prison. Unlike an intoxicated prisoner, they

115 See text accompanying note 103 supra. The Bailey intent test is essentially a relaxation of traditional duress notions. The requisite conditions, such as immediacy of the harm, are relevant but not determinative. The prisoner who escapes to visit his mother could still attempt to justify his escape on duress grounds, but would have difficulty in justifying his continued absence.

116585 F.2d at 1120 (Wilkey, J., dissenting).

11743 Cal. App. 3d 823, 118 Cal. Rptr. 110 (1974). See note 20 supra.

While the court and the dissent basically agree on what issues are relevant to weighing evidence of prison conditions in escape cases . . . the dissent would hold all such evidence irrelevant as a matter of law unless it is determined that every one of [the] five specific [Lovercamp] prerequisites related to these issues is met.

$585 \mathrm{~F} .2 \mathrm{~d}$ at $1096 \mathrm{n} .28$ (emphasis in original).

118 Id. 1106 (Wilkey, J., dissenting).

119 Moder Penal Code $\$ 2.02(2)$ (b) (ii) (Proposed Official Draft, 1962): "A person acts knowingly with respect to a material element of an offense when: ... (ii) if the element involves a result of his conduct, he is aware that it is practically certain that his conduct will cause such a result."

120585 F.2d at 1126 (Wilkey, J., dissenting). 
were quite aware of the consequences of their action; such general intent is sufficient. ${ }^{221}$ By contrast, the majority demands a higher level of intent, namely "purposive" action. ${ }^{122}$ For the majority, it is not enough if the jury finds that the escapee knew that he was leaving prison. Knowledge of the consequences of his behavior is insufficient. ${ }^{123}$ The jury must further ask what reasons compelled this choice, and must conclude that one of the prisoner's purposes in departing was to avoid confinement conditions. The question of motive and intent thereby becomes central.

This debate ultimately centers on the social utility of the competing definitions of escape. The resolution of such a dispute over practical politics demands an analysis of the effects of the majority's approach.

\section{Duress and Intent: Atrendant Effects of SHIFTING THE BURDEN}

The Bailey intent approach is primarily subjective: it mandates an examination of the defendant's mental state. This is a more relaxed test than the traditional duress approach, which combined both subjective and objective elements. ${ }^{124}$ Under the more lenient Bailey rule, generalized conditions alone may be sufficient to negate the voluntariness of the escapee. ${ }^{125}$ More importantly, the inquiry into a defendant's voluntariness is no longer dependent upon the defendant's ability to meet his burden of proving lack of intent as an affirmative defense. The voluntariness inquiry becomes instead a question of the defendant's intent, which the prosecution must prove beyond a reasonable doubt. ${ }^{126}$ This transfer of the burden of proof is likely to produce even more lenient results; the shifting of

121 Cf. People v. Noble, 18 Mich. App. 300, 303, 170 N.W.2d 916, 918 (1969) ("Defendant does not deny that he intended to leave the prison, and this is all the intent the law requires.").

122 Modec Penal Code $\$ 2.02(2)$ (a)(i) (Proposed Official Draft, 1962): “A person acts purposely with respect to a material element of an offense when: (i) if the element involves the nature of his conduct or a result thereof, it is his conscious object to engage in conduct of that nature or to cause such a result . ..."

123 For example, defendants who leave a prison due to guard brutality surely know that they are departing the grounds. But if their minds are solely focused upon escaping the brutality, the necessary "purposive action" is absent.

124 Under the traditional duress test the defendant must show that he was compelled to escape and that a reasonable person would similarly have been compelled. (And, of course, the danger must be imminent and impending, and likely to cause death or serious bodily injury.) See United States v. Bailey, 585 F.2d 1087, 1096 n.29 (D.C. Cir. 1978), cert. granted, 47 U.S.L.W. 3621 (U.S. 1979) (No. 78-990).

125 Rather than establish any specific threats, the defendant must merely show that "evidence of jail conditions, threats, and violence . . raises reasonable doubts concerning [his] . . . intent to avoid confinement." Id. 1094.

126 See text accompanying note 104 supra. 
the burden and the negation of intent by pleading generalized prison conditions will enable many more defendants to reach juries with evidence of intolerable prison conditions. Finally, Bailey, like other recent cases, ${ }^{127}$ evidences a general relaxation of the previous strict duress requirements that in many cases have precluded defendants from reaching the jury. ${ }^{128}$ This Comment concludes that the majority opinion in Bailey is properly sensitive to the plight of the prisoner in the present penal system. The opinion is, however, at times cavalier in its amendment of prior doctrine; it does not carefully justify its holdings, nor does it examine the implications of its actions. A complete analysis of Bailey must therefore examine its potential effect on the penal system and the individual defendant.

\section{A. The Potential Increase in Incidence of Escape}

Traditionally, the judiciary has limited, or even denied, the duress defense to escapees primarily because it has feared that a "rash" of escapes would ensue.129 Although many of the most recent cases have recognized the legitimate concerns of escapees, ${ }^{130}$ the underlying public policy considerations limiting potential excuses for escape have not thereby vanished. As a result, some courts have adopted strict conditions limiting the presentation of the duress defense in an attempt to satisfy both sides of the balance. ${ }^{131}$ Bailey's adoption of more lenient standards shifts that balance in favor of the escapee and presents the question whether this leniency ignores significant societal concerns.

127 See, e.g., People v. Unger, 33 Ill. App. 3d 770, 338 N.E.2d 442 (1975), aff'd, 66 Ill. $2 \mathrm{~d} 333,362$ N.E.2d 319 (1977).

128 See, e.g., People v. Hocquard, 64 Mich. App. 331, 337 n.3, 236 N.W.2d 72,75 n.3 (1975).

129 E.g., People v. Noble, 18 Mich. App. 300, 303, 170 N.W.2d 916, 918 (1969). See also State v. Palmer, 45 Del. 308, 72 A.2d 442 (Ct. Gen. Sess. 1950). It has been suggested that "[ $t]$ he solution must rather come from some kind of penological reform." People v. Noble, 18 Mich. App. 300, 303, 170 N.W.2d 916, 918 (1969).

130 See, e.g., People v. Lovercamp, 43 Cal. App. 3d 823, 118 Cal. Rptr. 110 (1974); Helton v. State, 311 So. $2 d 381$ (Fla. App. 1975); People v. Unger, 66 Ill. 2d 333, 362 N.E.2d 319 (1977); People v. Harmon, 394 Mich. 625, 232 N.W.2d 187 (1975). See note 42 supra.

Traditionally, the courts have balanced the interests of society against the immediate problems of the escaping defendant. This has tended to focus attention away from the immediate choices available to the defendant and the propriety of his cause of action. Thus, reprehensible conditions have been found to be insufficient to justify the escape, the public interest outweighing the defendant's interest.

People v. Lovercamp, 43 Cal. App. 3d 823, 827, 118 Cal. Rptr. 110, 112 (1974).

131 "While we conclude that under certain circumstances a defense of necessity may be proven by the defendant, at the same time we place rigid limitations on the viability of the defense in order to insure that the rights and interests of society will not be impinged upon." Id. 827, $118 \mathrm{Cal}$. Rptr. at 112. 
Courts have expressed fear that chaos would result if the duress defense were more readily available to escapees. This fear reflects an underlying assumption that there is a high potential for abuse of this defense. As one court stated, "it is easy to visualize a rash of escapes, all rationalized by unverifiable tales of sexual assault." 132 These courts felt that a readily available duress defense would add another element to an inmate's calculus when contemplating an escape: he would believe that if he were to be apprehended, he could avoid punishment by resorting to the excuse that his escape was compelled by a homosexual assault. These fears of the duress defense were largely groundless, for a tale of sexual assault demands that the defendant name his attacker. Barring the possibility of collusion among inmates, ${ }^{133}$ a defendant would be hard-pressed to meet this difficult condition. ${ }^{134}$

Under the Bailey intent test and its relaxation of prior doctrine, however, the fear of an increase in the number of unwarranted escapes does appear to be more justified. By easing the specificity of the harm that must be shown, Bailey requires the escapee only to point to intolerable conditions that have impinged upon his personal security. ${ }^{135}$ This is a less onerous burden, as intolerable conditions are prevalent in most prisons. An artful and shrewd defendant could at least arguably demonstrate that some of these have directly affected his health or safety. "To make it the province of every prisoner in every jail in the land to decide for himself whether conditions were so unbearable as to justify his escape would only serve to increase the number of attempts to break jail . . . "136

The danger of an increase in the number of escapes by prisoners who fabricate an intent to avoid non-confinement conditions is, how-

132 People v. Noble, 18 Mich. App. 300, 303, 170 N.W.2d 916, 918 (1969).

133 "[P]risoners might plot together and implement a plan which would look like one of their lives was being threatened. The 'threatened' inmate could then escape and plead duress if caught." Note, Duress and the Prison Escape: A New Use for an Old Defense, 45 S. CAL. L. Rev. 1062, 1081 (1972) (emphasis in original). Such collusion is highly implausible, for few inmates would be willing to bear the consequences of being the supposed assaulter.

134 Additionally, such a fear does not take into account other conditions typically imposed by courts that narrow the use of the duress defense, such as the return requirement. Indeed this requirement renders inapposite the fears expressed in People v. Noble, 18 Mich. App. 300, 170 N.W.2d 916 (1969). See text accompanying note 132 supra. At most a cunning inmate could get over the wall, at which point, under a standard definition of the return requirement, he must "immediately [report] to the proper authorities when he has attained a position of safety from the immediate threat." People v. Lovercamp, 43 Cal. App. 3d 823, 832, 118 Cal. Rptr. 110, 115 (1974). See text accompanying notes $137-45$ infra.

135 See text accompanying notes 48-59 supra.

136 State v. Palmer, 45 Del. 308, 310, 72 A.2d 442, 444 (Ct. Gen. Sess. 1950) (emphasis added). 
ever, undercut by the "return requirement." 137 This condition responds to societal concerns by severely limiting the time that the accused and convicted criminal can roam the streets. Chaos cannot result if the escapee must immediately surrender to the authorities. Although the Bailey intent test does not adhere to any "inflexible prerequisites," 188 including the return requirement, ${ }^{139}$ it does recognize that the escapee's failure or tardiness to return is one of "the most significant considerations" 140 for the jury. Whether the prisoner returns to custody remains an extremely important consideration in determining the defendant's intent. ${ }^{141}$ Although Bailey does not impose a rigid rule, it does not thereby undermine the reliance of other courts on the prerequisite of return as a means to effectuate a sensible balance between the needs of society and the prisoner.

The fact that the jury will be required to evaluate a defendant's intent under the Bailey rule provides a sufficient safeguard against the possibility of a multitude of phony "involuntary" escapes from intolerable prison conditions. A defendant must raise the issue of his voluntariness, "by competent evidence in a trial where the testimony of witnesses is subjected to the scrutiny of the fact-finder who, in the course of determining the true facts of the case, would properly consider the credibility of the various witnesses." ${ }^{142}$ The prosecutor, in meeting the burden of rebutting beyond a reasonable doubt the defendant's version of his intent, will be able to point out inconsistencies between the defendant's actions and what are often prerequisites to a duress defense in more rigid jurisdictions than the District of Columbia Circuit. Under the Bailey intent test, these prerequisites can serve as guidelines in aiding the fact-finder to determine the veracity of the defendant's claims. ${ }^{143}$ Bailey's relaxation of the return requirement must be viewed in this context. An escapee who does not immediately turn himself in is not thereby precluded from reaching the jury. Prac-

137 See, e.g., People v. Lovercamp, 43 Cal. App. 3d 823, 832, 118 Cal. Rptr. 110,115 (1974) ("The fear of unwarranted uses of the duress defense also fails to take into account the return requirement."); 43 U. CIN. L. REv. 956, 963 (1974). 138585 F.2d at 1096 n.28.

139 See note 20 supra.

140585 F.2d at 1096 n.28.

141 See text accompanying notes 107-11 supra.

142 People v. Harmon, 53 Mich. App. 482, 487, 220 N.W.2d 212, 215 (1975). Cf. United States v. Bailey, 585 F.2d 1087, 1096 n.28 (D.C. Cir. 1978), cert. granted, 47 U.S.L.W. 3621 (U.S. 1979) (No. 78-990) ("Once the defendant has presented a threshold amount of evidence, that evidence is to be considered by a properly instructed jury.").

143 See text accompanying notes 107-11 supra. See also People v. Unger, 66 Ill. $2 \mathrm{~d} 333,342,362$ N.E.2d 319,323 (1977). 
tically, however, he must still be able to convince the jury that he had a justifiable reason for waiting. ${ }^{144}$ It is exclusively the role of the jury, as the representative of the community, to judge the credibility of a defendant's story. "[T]he framework of the fact-finding process" 145 is the traditional means of ascertaining the truth of other defendants' tales; it should remain as the means of determining the basis of escapees' tales.

The Bailey opinion, in discussing both duress and intent, also relaxed the requirement of an impending injury of severe bodily harm, ${ }^{146}$ but the "severity of [prison] conditions" remains a relevant issue. ${ }^{147}$ Nevertheless, it is clearly easier for the jury to decide if the escapee was threatened with, or has suffered, serious bodily harm than to determine if generalized intolerable prison conditions impinged upon his personal security. If the latter determination is at issue, a shrewd escapee may be able to dupe the jury. But the criminal justice system's reliance on the role of the jury does not fluctuate with the relative ease of the particular fact-finding mission, and the possibility for error is present in all trials. If the defendant truly departed solely to avoid intolerable prison conditions of a serious nature, the jury's refusal to bring in a verdict of guilty would not in any way contribute to a rash of "unverifiable" escapes. If the prisoner escaped to avoid confinement conditions, the "traditional safeguards for determining the truth of a tale" 148 should be sufficient to preclude him from taking advantage of the

144 Escape continues to be a continuing offense. See text accompanying notes 10-15 supra. The intent test would still require that the intent in not returning to prison be to avoid non-confinement conditions. Cf. People v. Unger, 66 Ill. 2d 333, 342-43, 362 N.E.2d 319, 323 (1977):

[I]n the present case defendant did not report to the authorities immediately after securing his safety. In fact, defendant never voluntarily turned himself in to the proper officials. However, defendant testified that he intended to return to the prison upon obtaining legal advice from an attorney and claimed that he was attempting to get money from friends to pay for such counsel. Regardless of our opinion as to the believability of defendant's tale, this testimony, if accepted by the jury, would have negated any negative inference which would arise from defendant's failure to report to proper authorities after the escape.

Like Bailey, Unger recognizes the function of the jury as the trier of fact. Bailey specifically relies upon Unger in its rejection of the stringent requirements set forth in People v. Lovercamp, 43 Cal. App. 3d 823, 118 Cal. Rptr. 110 (1974), quoted in note 20 supra. 585 F.2d at 1096 n.28.

145 People v. Harmon, 53 Mich. App. 482, 488, 220 N.W.2d 212, 215 (1975).

146 The duress discussion in Bailey also appears to weaken the immediacy requirement. See part I supra. The intent test is more innovative, however, and subsumes the effect of the more lenient duress defense.

$147585 \mathrm{~F} .2 \mathrm{~d}$ at $1096 \mathrm{n} .28$.

148 People v. Harmon, 53 Mich. App. 482, 486, 220 N.W.2d 212, 215 (1975). 
Bailey option. ${ }^{149}$ Juries should not be assumed to be less competent to assess intent to escape than they are to determine intent in other contexts. Moreover, the return requirement operates as a continual check upon the possibilities for abuse of the Bailey alternatives. Escape remains a continuing offense, and the consideration of return remains a highly pertinent factor. The longer the escapee stays away from custody the more difficult will be his task of persuading the jury that his continued freedom was justifiable. The necessity of return is a constant factor which reflects society's interest.

Thus these two factors-the relevance of the return and use of the fact-finding process-combine to restrict the available opportunities for devious inmates to abuse the Bailey test. The public's interest is thereby safeguarded, and the interests of the victimized inmates are not ignored, for there are now "workable safeguards ... to protect their safety." 150

\section{B. Treatment of the Violent Escapee}

The fear of an increase in escapes reflects a related concern that additional escapes increase the possibility of injuries to innocent people inflicted by fleeing inmates. ${ }^{151}$ The legitimacy of this fear depends upon the assumption that additional escapes would in fact result. As we have seen, this fear is not well founded.152 A more difficult question under the Bailey intent test, however, is whether escapees who are truly fleeing from non-confinement conditions and who resort to violence to effectuate their escape are precluded from raising involuntariness arguments. Bailey does not hold that the intent test is available only when no force or violence has been used, ${ }^{153}$ nor does it adequately address the problem of the violent escapee. ${ }^{154}$ Although lack of violence is a central consideration for the trier of fact, it is not necessarily determinative. ${ }^{150}$ Presumably, then, there

149 "Juries are accustomed to determining the intent of alleged criminals, and we see nothing in the context of prosecutions for escape that requires the court to risk denying the defendants a fair trial by denying the jury its normal function." 585 F.2d at 1096.

150 People v. Harmon, 53 Mich. App. 482, 486, 220 N.W.2d 212, 215 (1975). 151 E.g., People v. Whipple, 100 Cal. App. 261, 279 P. 1008 (1929); State v. Palmer, 45 Del. 308, 72 A.2d 442 (Ct. Gen. Sess. 1950).

152 See text accompanying notes 137-50 supra.

153585 F.2d at 1096 n.28. The duress defense was often held to be unavailable when any force or violence was used. See the requirements established in People v. Lovercamp, 43 Cal. App. 3d 823, 118 Cal. Rptr. 110 (1974), quoted in note 20 supra.

154 See text accompanying notes 93-98 supra.

155585 F.2d at 1096 n.28. 
may be instances in which an escapee injures a guard but is nonetheless exonerated from the crime of escape. ${ }^{158}$

There are a number of possible ways to deal with the otherwise credible defendant who resorts to force or violence in effecting his escape. One would be to preclude a defendant from gaining the benefit of the intent test and from employing involuntariness arguments entirely. Bailey clearly rejects this route. ${ }^{157}$ Although this approach takes into account the societal interest in non-violence, as was noted earlier, it is inconsistent with the rationales underlying the creation of the intent test. ${ }^{158}$ A more sensible response to the violent prisoner would be to allow the defendant to reach the jury, and perhaps even to be found innocent of the crime of escape itself, but also to face additional criminal charges for the violence that accompanied his escape. This approach is consistent with the intent notions that underlie the Bailey model.159 A last approach that is consistent with the Bailey opinion would allow the violent escapee to employ involuntariness arguments, and conceivably to be excused for both the crime of escape and for the violence used to effectuate that escape. Such a resolution is fully consistent with the notions of intent that underlie prison-escape prosecutions; it is also responsive to the notions of duress that characterize the criminal law generally. It recognizes that duress may characterize all actions of the escapee, not merely the physical act of climbing over the wall. In the process of escaping, the inmate may be "unable" to form the requisite criminal intent to engage in acts of violence because the involuntariness that marks his behavior in escaping affects all of his immediate actions in effectuating the escape. The use of an involuntariness argument to justify the use of violence in the escape should only be allowed, however, if the initial intolerable prison condition was a threatened harm of death or serious bodily injury-the prerequisite for the duress defense generally. The effects of exonerating the escapee for both the escape and the attendant violence would not tip the balance in favor of the escapee at the expense of society. The criminal law does not ordinarily punish those who are unable to formulate the necessary criminal intent: without the necessary mens rea the actor is not held accountable for his actions. This approach may well be the most appropriate response in the extraordinary case of an

156 Bailey's ambiguity in this regard is understandable, for the instant defendants did not resort to violence.

157 See text accompanying notes 153-56 supra.

158 See text accompanying notes 93-98 supra.

159 Id. 
escapee who resorts to violence because he is in a state of duress which taints both his act of departing confinement and his concomitant efforts to effectuate his escape. ${ }^{160}$

\section{ConcLUSION}

United States $\boldsymbol{v}$. Bailey represents a high water mark in the judiciary's growing recognition of the rights of the incarcerated. Although the opinion is marked by acute sensitivity to the plight of the defenseless prisoner, the ultimate solution to the severe endemic problems of penal institutions must come from the legislature. Short of releasing prisoners, ${ }^{101}$ the judiciary's role is limited to excusing those who resort to self-help. Although the consequences are less pernicious than further punishment, there are no winners at such trials, for the defendant has already escaped, and suffered, intolerable penal conditions. Although Bailey may aid him in avoiding further punishment, it does not afford him his outright release. He must return to the same set of conditions in order to serve the remainder of his original sentence. If he returns to the same prison his former assailants will renew their assaults; if he is returned to another prison, there can be no guarantee that he will be safe from other attacks. In either case, the acquitted prisoner must again learn to cope in an atmosphere fraught with continual threats to his personal security.

$160 \mathrm{~A}$ final concern evinced by the judiciary with respect to the self-help measure of escape is the fear that prison breaks would be disruptive of prison discipline, routine, and morale. People v. Whipple, 100 Cal. App. 261, 279 P. 1008 (1929); State v. Palmer, 45 Del. 308, 310, 72 A.2d 442 (Ct. Gen. Sess. 1950). This objection is outdated, however; more recent cases, even those rejecting the duress defense, have not raised this argument. See, e.g., People v. Noble, 18 Mich. App. 300, 170 N.W.2d 916 (1969); State v. Green, 470 S.W.2d 565 (Mo. 1971) (en banc), cert. denied, 405 U.S. 1072 (1972). Prison discipline and order are indeed laudable societal goals. But they should not be allowed to outweigh the legitimate concerns of an inmate who has escaped precisely because prison discipline and routine can not protect him from threat and attack. To prevent this escapee from raising involuntariness arguments would be incongruous. It would punish the inevitable byproduct of the penal system, but ignore, and thus encourage, the underlying causes. A more effective method of improving prison order would be to ameliorate the problem itself rather than to punish further those who have been harmed by the lawlessness and disorder. Such an approach would thereby reduce the incidence of excusable prison escapes.

If the conditions of our penal institutions have reached the point where the only recourse to free oneself from unwanted personal attacks is to flee, then any improvements made in our prisons with respect to assuring the personal safety of the inmates could only serve to eliminate from the ranks of escapees those who do so solely in an effort to protect themselves. The result, therefore, might well be fewer prison escapes rather than more.

People v. Harmon, 53 Mich. App. 482, 487-88, 220 N.W.2d 212, 215 (1975).

161 See, e.g., Rhem v. Malcolm, 377 F. Supp. 995 (S.D.N.Y.), modified, 507 F.2d 333 (2d Cir. 1974) (court enjoined further confinement at the Manhattan House of Detention for Men (the "Tombs") because conditions and practices at the institution violated the constitutional rights of detainees). 